\title{
Using Data Mining In Learning Management Systems Amidst Covid-19
}

\author{
Froilan D. Mobo \\ Philippine Merchant Marine Academy \\ e-mail: frolanmobo@gmail.com
}

Received: 08 Juli 2020; Revised: 21 Agustus 2020; Accepted: 28 Agustus 2020
DOI: $\underline{\text { http://dx.doi.org/10.37905/aksara.6.2.97-102.2020 }}$

\begin{abstract}
The Second Semester of Academic Year 2019-2020 was temporarily suspended due to the widespread COVID-19 last March 16, 2020, forcing the President of the Republic of the Philippines, Hon. Rodrigo Roa Duterte imposed an Enhanced Community Quarantine in Luzon which is known as a lockdown closing all the border points of each town and provinces. One of the major problem encountered during the lockdown is the suspension of classes because as per IATF guidelines you need to stay home, the said Memorandum Order was posted in the official gazette, (Medialdea, 2020)

The dataset on the features of the Learning Management Systems using Moodle is that Professors will be the one who will set the topics, quizzes, and exercises for his class even the assessment methods on the system. To prevent from slowing down the network, the Team of Seaversity the developer of the learning management systems headed by $\mathrm{C} / \mathrm{E}$ Ephrem Dela Cernan conducts a ZOOM Training to all Faculty to be familiarized more on the Learning Management Systems of the Philippine Merchant Marine Academy.

The Moodle Learning Management Systems is a user-friendly environment because of its features and users can easily adjust from the traditional face to face teaching going to e-Learning approach because of it's all capabilities as a data mining methods such as statistics, association rule mining, pattern mining visualization, categorization, clustering, and text mining., (AlAjmi \& Shakir, 2013)
\end{abstract}

Keywords - Data Mining, COVID19, Learning Management System

\section{INTRODUCTION}

The Second Semester of Academic Year 2019-2020 was temporarily suspended due to the widespread COVID-19 last March 16, 2020, forcing the President of the Republic of the Philippines, Hon. Rodrigo Roa Duterte imposed an Enhanced Community Quarantine in Luzon which is known as a lockdown closing all the border points of each town and provinces. One of the major problem encountered during the lockdown is the suspension of classes because as per IATF guidelines you need to stay home, the said Memorandum Order was posted in the official gazette, (Medialdea, 2020)

The Commission on Higher Education is already providing training to higher education institutions and setting up connectivity in preparation for the need to adopt a learning management system and decide to use online learning amid threats of COVID19. (Ferrer, 2020). The Philippine Merchant Marine Academy has created an alternative way to continue the study of cadets even if traditional methods are suspended. One of the administration's thought is Learning Management Systems using moodle. Because 


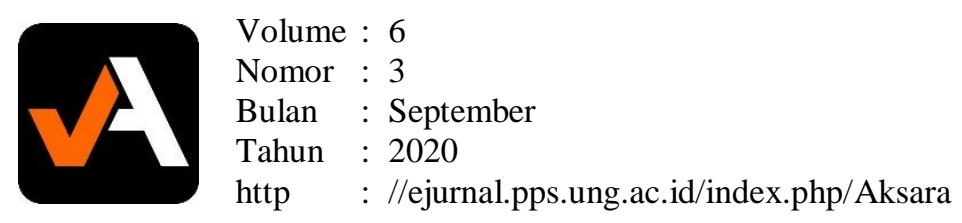

Moodle LMS is already capable in data mining methods used, such as statistics, association rule mining, pattern mining visualization, categorization, clustering, and text mining, (AlAjmi \& Shakir, 2013) These are packages which include the Learning Management Systems using Moodle. Moreover, building an adaptive learning management system based on learning styles is a very stimulating task. Two approaches to determine students culture style are mainly used: using questionnaires or data mining techniques on Learning Management Systems log data., (Kika, Leka, Maxhelaku, \& Ktona, 2019)

\section{Dataset and Description of Features}

The dataset on the features of the Learning Management Systems using Moodle is that Professors will be the one who will set the topics, quizzes, and exercises for his class even the assessment methods on the system. To prevent from slowing down the network, the Team of Seaversity the developer of the learning management systems headed by $\mathrm{C} / \mathrm{E}$ Ephrem Dela Cernan conducts a ZOOM Training to all Faculty to be familiarized more on the Learning Management Systems of the Philippine Merchant Marine Academy.

Moreover, despite the results, Moodle has been a great potential, it is mainly used as a repository of materials. However, students and faculty recognize the importance of the use of other functionalities of the moodle platform to promote the success of the teaching/learning process., (Costa, Alvelos, \& Teixeira, 2012).

The Philippine Merchant Marine Academy Learning Management System is accessible via https://pmma.seaversity.com.ph/login/index.php. According to (Moodle, 2020), the Main features of the Moodle LMS are the following:

- Educators and learners can track development and completion with a collection of options for following individual activities or resources and at a course.

- Designed to be reactive and accessible, the Moodle interface is easy to navigate together with desktop and mobile device

- Format text and conveniently and add media and images with an editor that works across all cross sectional web browsers and devices.

- Users can get automatic alerts on new assignments and deadlines, forum posts, and also send private messages to one another.

- Educators and students can trail progress and completion with collections of all activities.

\section{METHODOLOGY}

- Moodle Learning Management System version 3.8.3+ is an open source under the GPL licence and can be downloaded at https://download.moodle.org/

- Moodle Learning Management Systems version 3.8.3+ is already capable in data mining methods used, such as statistics, association rule mining, pattern mining visualization, categorization, clustering, and text mining., (AlAjmi \& Shakir, 2013)

- Educators and learners can track progress and completion with a range of options for tracking individual activities or resources and at a course. 
Volume : 06

Nomor : 03

Bulan : September

Tahun : 2020

http : //ejurnal.pps.ung.ac.id/index.php/Aksara

\section{Step-by-Step Solution}



1. Log-in Form of the Learning Management System using Moodle

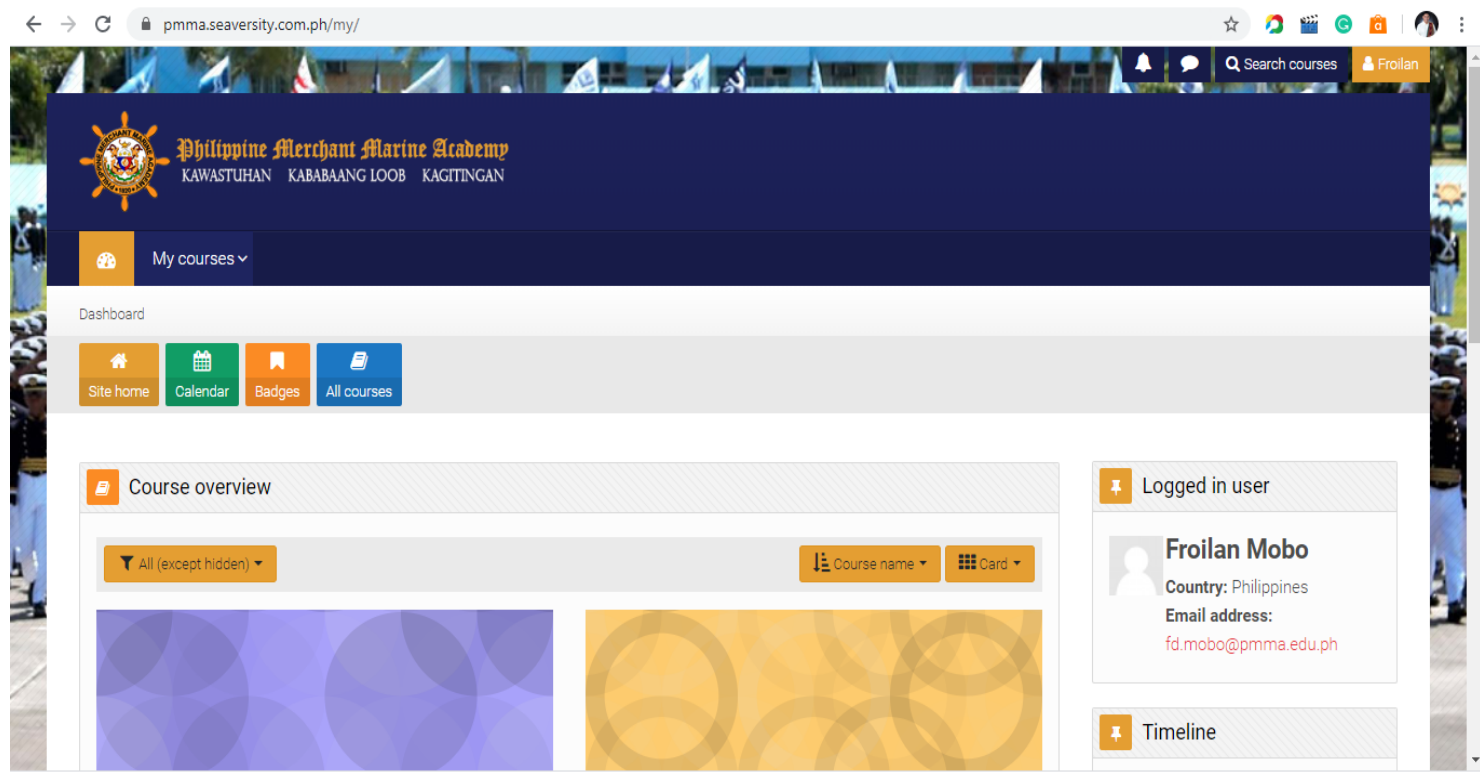

2. Dash Board: Where the Professor/s can post their assignment and exercises 


\section{RESULTS \& DISCUSSION}

The Moodle Learning Management Systems is a user-friendly environment because of its features and users can easily adjust from the traditional face to face teaching going to e-Learning approach because of it's all capabilities as a data mining methods such as statistics, association rule mining, pattern mining visualization, categorization, clustering, and text mining., (AlAjmi \& Shakir, 2013) When answering assignments and exercises online and also by doing the assessment plus its capability to analyze a problem. In the learning field, it is very conducive both for faculty and students to use data mining software because even it is online learning, the student will gauged still in different methods of teaching delivery using the learning management system.

\section{ACKNOWLEDGEMENT}

This article has no life if not for these people who always inspired me to do better in everything that I do, I offer all of my works for them because my success is also theirs. Thank you for my son Kenneth Froy Angelo Mobo, to Ms. Ana Liza Garcia and to Rev. Fr. Willie who is always supportive to me. Their Love and prayers kept me strong and efficient in my works. But most of all, Thanks be to God for all the guidance and blessings.

\section{REFERENCES}

AlAjmi, M., \& Shakir, K. (2013, March). DATA MINING IN LEARNING MANAGEMENT SYSTEM UTILIZING MOODLE. Retrieved from https://library.iated.org/view/ALAJMI2013DAT

Costa, C., Alvelos, H., \& Teixeira, L. (2012). The Use of Moodle e-learning Platform: A Study in a Portuguese University. Procedia Technology, 5, 334-343. doi: 10.1016/j.protcy.2012.09.037

Ferrer, R. (2020, May 5). Ilang pamantasan sa bansa, inaasistihan na ng CHED sa paggamit ng online learning. Retrieved from https://www.covid19.gov.ph/ilang-pamantasan-sa-bansa-inaasistihan-na-ngched-sa-paggamit-ng-online-learning/

Kika, A., Leka, L., Maxhelaku, S., \& Ktona, A. (2019). Using Data Mining Techniques On Moodle Data For Classification Of Student'S Learning Styles. Proceedings of the 47th International Academic Conference, Prague. doi: 10.20472/iac.2019.047.010

Medialdea, S. C. (2020, March 18). Memorandum from the Executive Secretary On Community Quarantine over the Entire Luzon and Management of the Coronavirus Disease 2019 (COVID-19) Situation: GOVPH. Retrieved from https://www.officialgazette.gov.ph/2020/03/18/memorandum-from-theexecutive-secretary-on-community-quarantine-over-the-entire-luzon-andmanagement-of-the-coronavirus-disease-2019-covid-19-situation/

Moodle (2020). Moodle Features. Retrieved from https://docs.moodle.org/38/en/Features 